\title{
PERSPECTIVES OF APPROPRIATE NON-PRODUCTIVE LAND USE IN LITHUANIA
}

\author{
Edita Abalikstiene ${ }^{1}$, Daiva Gudritiene ${ }^{1,2}$ \\ ${ }^{1}$ Kaunas Forestry and Environmental Engineering University of Applied Sciences, \\ ${ }^{2}$ Aleksandras Stulginskis University
}

\begin{abstract}
The average land productivity score is about 41.8 in the Republic of Lithuania. However, in separate regions it ranges from 30.5 to 55.1. The research object is agricultural utilities in rural municipalities of the Republic of Lithuania. The analysis of land use plan fragments in the selected areas shows that land is abandoned mostly in land areas where non-productive land or hilly relief prevails. Having improved conditions of land use, about 44 $\%$ of abandoned agricultural utilities can be transferred into intensive farming.
\end{abstract}

Key words: non-productive land, unused land, land use

\section{Introduction}

Preservation of land suitable for agriculture and its appropriate consumption is an important aim worldwide. The problem is specific as agricultural land is limited and in practice non-renewable natural resource. Therefore, the legal regulation stating that land plots for agricultural purposes must be used for agricultural activity only by their owners and/or consumers must be issued. (Abalikstiene, Aleknavicius, 2013; Abalikstiene, Stravinskiene, 2011; Aleknavicius, 2007, 2010, 2012; Krisciukaitiene et al, 2009; Kuliesis, Salengaite, 2010; Sinkeviciute, Gudritiene, 2011).

Lithuanian municipalities with the average land productivity less than 37 scores were selected as the research object. Land in 18 rural munisipalities out of 52 rural municipalities scored less than 37. In non-productive areas it is important to identify the most reasonable use of land regarding economic, social, environmental and technological aspects. The use of land considered as less favourable for agriculture was evaluated by conducting the research into abandonment of less favourable areas seeking EU support, good agrarian state practice, and support for rural communities. (Hatna, Bakker, 2011; Pelucha, Kveton, Jilkova, 2013; Bouma et al, 2012; Pasztor, Szabo, Bakacsi, 2010).

The research object is non-productive land for agricultural purposes in rural municipalities of the Republic of Lithuania. The aim of the research is to analyse prospects of rational non-productive land use in Lithuania. The following objectives were set to reach the aim: evaluate land use changes on the basis of cartographic material; to design methodological regulations for land use planning. The scientific novelty and practical relevance is the analysis of agricultural land use in non-productive areas on the basis of cartographic sources.

\section{Methodology of research and materials}

The methods of information search, systemising, the analysis of cartographic material and statistical data as well as scientific and methodological literature analysis, comparative analysis, and generalization were employed to reach the aims and objectives of the paper.

The main data for the research were obtained in the National Land Service under the Ministry of Agriculture, the State Land Fund, National Paying Agency under the Ministry of Agriculture, and the Register Centre. Cartographic data and databases found in Land Information System were used for analytical research.

\section{Discussions and results}

The analysis of reasonable non-productive land use allows us to state the main methodological principles for the change of existing land use, which can be employed:

- when preparing territory planning documents, which predict the change of land utility composition (first of all, transforming agricultural utilities into other utilities as well as transforming other land utilities and abandoned land into arable land, agricultural meadows, or forest (forest land)); 
- by optimizing the support for subjects of agricultural activity, which would induce one to use land by assessing its natural and farming qualities;

- when planning prospects of agricultural land users' activity;

- when planning the funding for drainage, other work of land improvement, and infrastructure equipment;

- while giving a permit to cultivate forest in agricultural utilities.

One of the most significant principles when determining prospects of non-productive land use is assessing the possibilities to realize the predicted changes and measures. The second principle is the balance of all interested people's suggestions and demands.

Changes of land use in cartographic material. When cartographic material designed during different periods is available, one can identify changes of agricultural land utilities and their causes.

Arbitrary signs in the images mark:

- agricultural land utilities in use (as declared);

- former agricultural utilities, which have turned into other utilities and have not been connected to control blocks for declaration of agricultural utilities and crop;

| - areas of former agricultural utilities connected to control blocks but not used (nondeclared); according to conducted distance research ascribed to abandoned lands (i.e. starting to be overgrown by trees and bushes);

- other uncultivated (not declared) agricultural land utilities connected to control blocks.

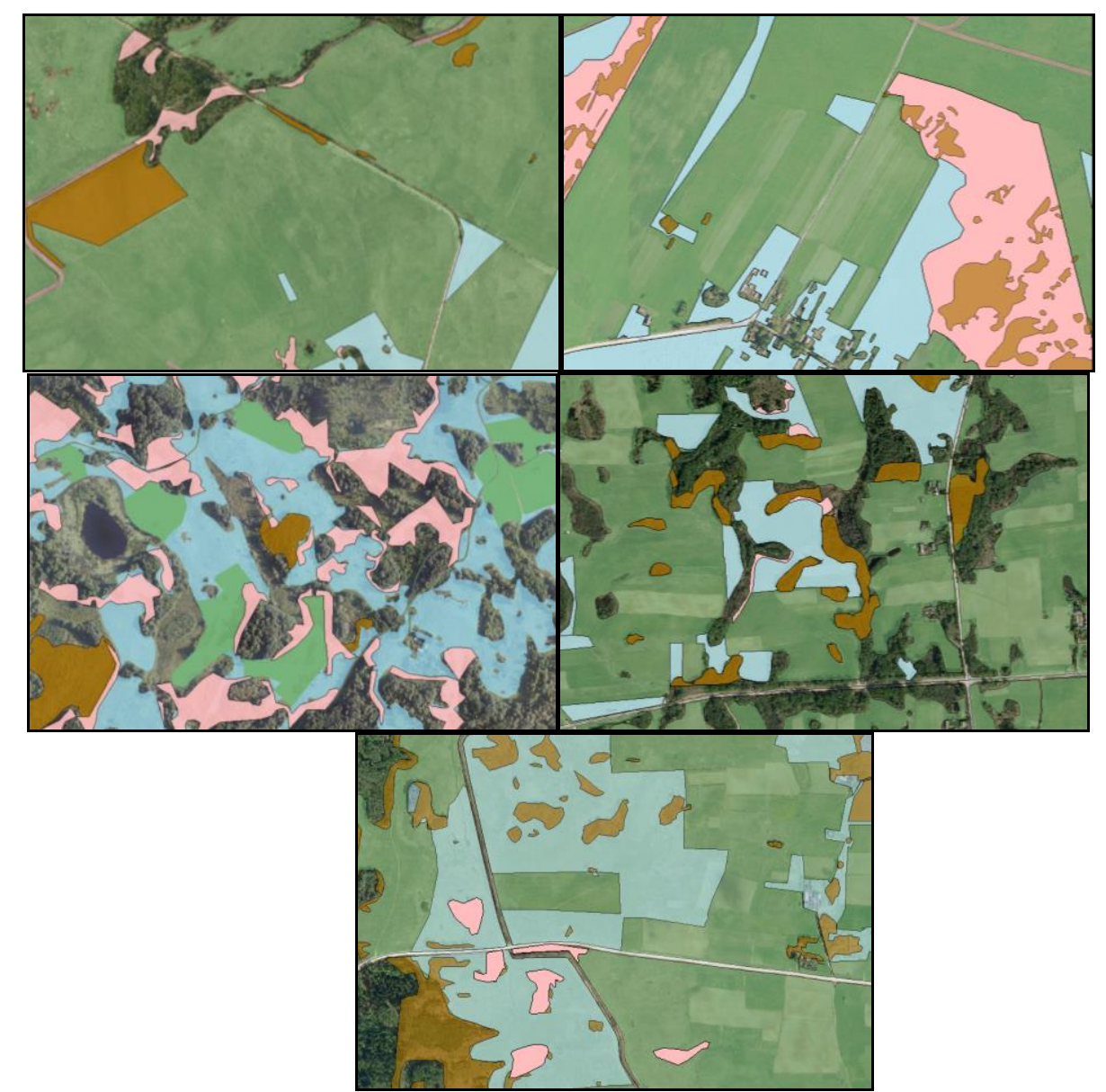

Fig. 1. Land use (plan fragments)

Following the analysis of provided examples, one can make the conclusion about the causes of agricultural land utilities deterioration or abandonment (Fig. 1). Unused agricultural utilities could be subdivided in the following way: 
1) land plots where agricultural activity is not pursued. These are territories where the forest is cultivated after obtaining the permit, former gardens in farmsteads are used as green areas, land areas are included into the territory of extended farmsteads or used for construction and equipment;

2) former meadows and natural pasture no longer in use, land has overgrown with shrubs, forests or turned into non-used land (the number of families keeping domestic animals had reduced and detached farmsteads had disappeared when rural inhabitants stopped keeping cows, calves, sheep and horses);

3) former plots of agricultural utilities are not used (not declared) due to reclamation system's defects; 4) former plots of arable land are not used (not declared) due to inconvenience: the small size of a plot, not embedded among agricultural utilities, long distance from arable land fields and good quality roads;

5) other former arable land and pasture plots near good roads or farmsteads have started to overgrow with trees and shrubs or are uncultivated due to non-productive lands and other causes (land owners do not have possibilities or do not wish to undertake agricultural activity, there are no farmers capable of hiring the land).

The analysis of land use plan fragments in selected areas showed that land was abandoned mostly in land areas where non-productive land or hilly relief prevail.

Table 1

Reasons of unused agricultural utilities in the analysed areas of non-productive lands

\begin{tabular}{|l|c|c|c|c|c|}
\hline \multicolumn{1}{|c|}{ Indices } & \multicolumn{5}{c|}{ Location (villages) } \\
\cline { 2 - 6 } & $\begin{array}{c}\text { Paukste- } \\
\text { liskes }\end{array}$ & $\begin{array}{c}\text { Mergis- } \\
\text { kes }\end{array}$ & Ropiskes & Buniskiai & Sadziunai \\
\hline I. Land area in the territory analysed, ha: & 73.6 & 73.9 & 73.9 & 74.1 & 74.4 \\
\hline I. 1. Area of former agricultural utilities, ha & 69.3 & 40.8 & 71.8 & 55.9 & 69.3 \\
\hline I. 2. Out of which : & & & & & \\
\hline $\begin{array}{l}\text { 1) turned into different kind of utilities and have not } \\
\text { been connected to crop declaration control blocks }\end{array}$ & 3.9 & 4.1 & 4.0 & 4.8 & 9.6 \\
\hline $\begin{array}{l}\text { 2) have been connected to control Bl1 blocks, } \\
\text { though not declared }\end{array}$ & 3.8 & 27.8 & 22.7 & 8.1 & 21.9 \\
\hline 3) area in use (declared) & 61.6 & 8.9 & 45.1 & 43.0 & 37.8 \\
\hline $\begin{array}{l}\text { II. Causes decrease in former agricultural utilities, } \\
\text { ha }\end{array}$ & & & & & \\
\hline $\begin{array}{l}\text { II. 1. Land areas which have been cultivated with } \\
\text { forest after obtaining the permit }\end{array}$ & - & - & - & - & - \\
\hline $\begin{array}{l}\text { II. 2. Former gardens in farmsteads used as green } \\
\text { areas; land plots used for construction or extension } \\
\text { of farmsteads }\end{array}$ & - & - & - & 0.5 & 0.7 \\
\hline $\begin{array}{l}\text { II. 3. Former meadows or natural pasture, not used } \\
\text { due to the lack of necessity }\end{array}$ & 0.4 & 4.1 & 3.4 & 1.7 & 5.6 \\
\hline $\begin{array}{l}\text { II. 4. Former plots of agricultural utilities, not used } \\
\text { (not declared) due to defects in reclamation systems }\end{array}$ & - & - & - & - & 1.7 \\
\hline $\begin{array}{l}\text { II. 5. Former plots of arrable land, not cultivated (not } \\
\text { declared) due to inconvenience: }\end{array}$ & & & & & \\
\hline - small size of the plot & 0.1 & - & - & 2.3 & 1.3 \\
\hline - have been situated outside agricultural utilities & - & - & - & - & - \\
\hline $\begin{array}{l}\text { - long distance from the arable land fields and good } \\
\text { quality roads }\end{array}$ & - & 10.2 & - & 2.5 & 0.5 \\
\hline $\begin{array}{l}\text { II. 6. Other plots of arable land and pasture unused } \\
\text { due to: }\end{array}$ & & & & & \\
\hline - low fertility (productivity score up to 30) & - & 10.5 & 19.8 & 2.8 & 4.9 \\
\hline - low farming value (productivity score - 31-35) & 3.5 & & 3.5 & - & - \\
\hline - overgrown with shrubs near forests & 0.7 & 7.1 & - & 3.1 & 4.8 \\
\hline - other reasons & 3.0 & & - & - & 12.0 \\
\hline
\end{tabular}


The research data shows that most of land abandonment cases occur in areas (see Fig. 2) where nonproductive land and hilly relief are dominating. $27.3 \%$ of former agricultural utilities are not used although they have road access whereas soil is of average farming value.

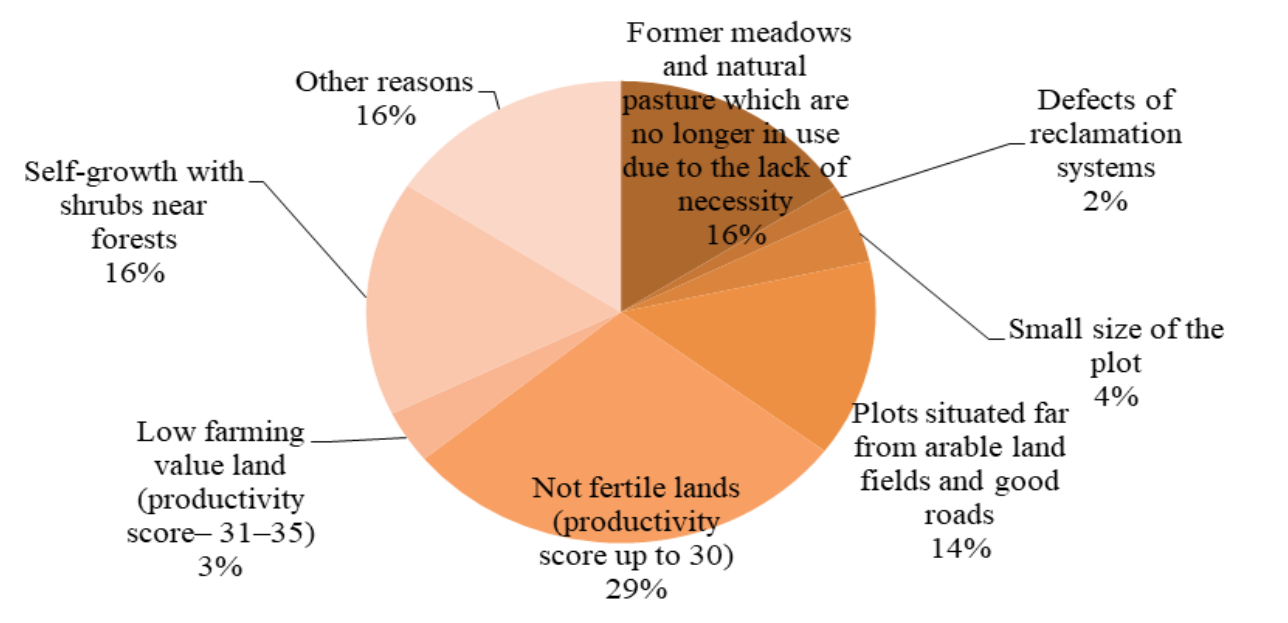

Fig. 2. Causes of decrease in agricultural utilities

Therefore, it is advisable to use the land for the purpose. Having improved conditions of land use, about $44 \%$ of abandoned agricultural utilities can be transferred to intensive farming.

Methodological principles for land use planning. While preparing documents of agrarian territoryplanning, the procedure, which would allow using more thorough assessment of the present state and soil examination material, is suggested. It includes the following information:

1. Definition of where and for what reasons former agricultural utilities have changed - their area has transformed into forests, shrub and tree greeneries, marshes, other unused land or is not used for cultivation (in bare fallow, is abandoned). The results of the analysis must be marked by conventional signs in cartographic material.

2. While compiling the drawing of planning document solutions, the areas (abandoned or changed) are defined and recommended for the certain directions of use:

1) for arable land - land plots or their parts, the soil of which is suitable for cultivation of annual plant crops. Only the land plots smaller than 0.5 ha can be an exception, not used due to straightening of land plot boundaries as well as spontaneously growing forest plantations in the abandoned land, which, during forest management activities were recorded and registered as forest (forest land);

2) for agricultural meadows - land plots or their parts, where earlier after essential reclamation measures, agricultural meadows were established; or these are the areas of drained peaty and humus soils larger than 0.5 ha or the land area with eroded soils on hills and in valleys, the slope inclination of which exceeds $5-7^{0}$. Agricultural meadows can also be established in small plots of current or former arable land, which, due to its small size is not appropriate to be used for mechanical cultivation from economic point of view or the access roads cannot be improved for the same reason. Only abandoned land plots overgrown with shrubs containing drainage systems of poor or satisfying condition, where it is not efficient to use machinery for cultivation of agricultural meadows and exploitation, can be an exemption;

3 ) on the basis of the current state for natural land utilities, the remaining area of former agricultural utilities overgrown with shrubs and trees or having changed into marshes or water pools. Natural meadows and pastures, which must not be drained, ploughed, or the state of which and composition of herbs cannot be changed in some other ways, are also attributed to the areas.

4) for cultivation of forest and field protective tree and shrub greeneries - the remaining area of unused (abandoned) agricultural utilities, the cultivation of forest is not against the law.

3. When planning transformation of agricultural utilities, to assess the possibility to realize changes mentioned in Section 2 by land users themselves or when pursuing the foreseen drainage reconstruction work in reclamation projects. It is also crucial to assess ecological diversity of landscape and identify greeneries for soil preservation or the ones which should be protected because 
of their value from an ecological point of view. The remaining insignificant tree and shrub greeneries in reclamation projects, land areas changed into marsh or unused plots having soil suitable for crop growing can be transformed into agricultural utilities.

4. Having completed the actions provided in Sections 2 and 3, it is crucial to analyse the current possibilities and to cultivate non-productive agricultural utilities with the forest. While preparing methodological recommendations, it is advisable to use the suggestions of the performed scientific research (Zemes..., 2011) concerning propsects of land use. New forests in agricultural utilities in use can be designed on the basis of the suggestions only if it is reasonable with regard to rural cultural landscape formation under the guidance of the main regulations and requirements, concerning the increase of Lithuanian forest coverage.

\section{Conclusions}

1. Having conducted the analysis of land use plan fragments in the selected areas, it was defined that land is abandoned mostly in land areas where non-productive land or hilly relief prevails. Having improved conditions of land use, about $44 \%$ of abandoned agricultural utilities can be transferred to intensive farming.

2. While preparing documents of the agrarian territory planning, such a procedure is suggested which would allow the use of more thorough assessment of the present state and soil examination material.

\section{References}

1. Abalikštienè E., Aleknavičius P. (2013) Žemès ūkio paskirties žemės naudojimo tendencijos savivaldybèse su vyraujančiomis nenašiomis žemèmis. Žemés ükio mokslai. T. 20, Nr. 3, p. 133-148.

2. Abalikštienė E., Stravinskienė V. (2011) Land use analysis in southeastern Lithuania. Rural Development 2011. Proceedings of the International Scientific conference. p. 372-377.

3. Aleknavičius A., Aleknavičius, P. (2010) Žemès ūkio naudmenų ploto pokyčių perspektyvos Lietuvoje. LŽŪU mokslo darbai. T. 86 (39), p. 28-36.

4. Aleknavičius P. (2007) Kaimiškujų teritorijų žemès naudojimo problemos. Žemés ükio mokslai. T.14 Nr.1, p. 82-90.

5. Aleknavičius P. (2012) Nepriklausomoje Lietuvoje atliktų žemès ūkio paskirties žemès pertvarkymo darbų lyginamoji analizè. Viešoji politika ir administravimas. T. 11 Nr. 2, p. 246-259.

6. Bouma J., Broll G., Crane T.A., Dewitte O. (2012) Soil information in support of policy making and awareness raising. // Current Opinion in Environmental Sustainability. Vol. 4, Issue 5, p. 552-558.

7. Hatna E., Bakker M. (2011) Abandonment and Expansion of Arable Land in Europe. Ecosystems. Vol. 14, Issue 5, p. 720-731.

8. Kriščiukaitienė I., Galnaityte A., Jedik A. et al. (2009) Analysis of agricultural policy scenario impacts on Lithuanian agriculture. Žemès ūkio mokslai. T. 16, Nr. 3-4, p. 101-112.

9. Kuliešis G., Šalengaitė D. (2010) Apleista žemė Lietuvoje: problemos, galimi sprendimo būdai. Management theory and studies for rural business and infrastructure development. Nr. 5 (24), p. 116-127.

10. Pásztor L., Szabó J., Bakacsi Z. (2010) Application of the Digital Kreybig Soil Information System for the delineation of naturally handicapped areas in Hungary. Akadémiai Kiadó. Vol. 59, No. 1, p. 47-56.

11. Pelucha M., Kveton V., Jilkova J. (2013) Territorial dimensions of agro-environmental measures and LFA in rural development policy in the Czech Republic. Land Use Policy. Vol. 34, p. 91-103.

12. Sinkevičiūtè V., Gudritienè D. (2011) Analysis of rural landscape structure use in Southern Lithuania. Baltic surveying'11. Proceedings of the International Scientific conference. p. 132-137.

13. Žemès naudojimo priemoniu mokslinis pagrindimas. $2011 \mathrm{~m}$. galutine ataskaita. Tyrimo vadovas V. Gurklys, Aleksandro stulginskio universitetas, Kaunas, 2011. p. 282.

\section{Information about authors}

Edita Abalikstiene. Assoc. professor dr. of Department of Real Estate Cadastre, Faculty of Environmental Engineering, Kaunas Forestry and Environmental Engineering University of Applied Sciences. Address: Liepu g. 1, Girionys, LT 53101, Kauno r., Lithuania, Tel.. +370 37 383082, e-mail: e.abalikstiene@ kmaik.lm.lt

Daiva Gudritiene. Lecturer, Department of Land Management, Faculty of Water and Land Management, Aleksandras Stulginskis University. Address: Universiteto 10, LT-53361, Akademija, Kaunas r., Lithuania, Tel. + 37037 752372. Lecturer, Faculty of Environmental Engineering, Kaunas Forestry and Environmental Engineering University of Applied Sciences. Address: Liepu g. 1, Girionys, LT 53101, Kauno r., Lithuania, Tel. +37037383082 e-mail: gudritiene@ @mail.com. 